Article

\title{
Implementation of Ecommerce on Small and Medium Enterprise
}

\author{
Tugiman ${ }^{1}$,Delih Wijaya ${ }^{2}$, Yakub $^{3}$, \\ ${ }^{1,2}$ Buddhi Dharma University, Information System, Banten, Indonesia \\ ${ }^{3}$ Buddhi Dharma University, Informatics Engineering, Banten, Indonesia \\ SUBMISSION TRACK \\ Recieved: February 18, 2021 \\ Final Revision: February 26, 2021 \\ Available Online: March 15, 2021

\section{KEYWORD} \\ E-commerce, Small and Medium Enterprise, \\ User Acceptance Test \\ CORRESPONDENCE \\ E-mail: ${ }^{1}$ Tugiman0311@gmail.com, \\ A B S S T R A A C T

The trend of information system development and technological
developments is continuously increasing. Every person or business
actor must continuously update the technology. Based on the
published results of a survey conducted by Indonesian Internet
Service Providers Association at the end of 2018, internet users in
Indonesia reached 171.17 million from 264.16 million people or
$64.8 \%$ of the total population.. Related to this, the researchers
conducted research on the implementation of e-commerce in
Small and Medium Enterprise. Testing of this study uses the User
Acceptance Test. The method that the authors do is by making a
system that is applied to Small and Medium Enterprise. To find
out about the acceptance of the system and its uses related to e-
commerce, the author uses a questionnaire method. Based on the
Black Box examiner all test results show valid, while the examiner
using the User Acceptance Test produces a number of $80.5 \%$ with
good criteria. The answers used in this study may be 39 people. \\ The trend of information system development and technological \\ developments is continuously increasing. Every person or business \\ Service Providers Association at the end of 2018, internet users in \\ people or \\ conducted research on the implementation of e-commerce in \\ Small and Medium Enterprise. Testing of this study uses the User \\ Acceptance Test. The method that the authors do is by making a \\ system that is applied to Small and Medium Enterprise. To find \\ commerce, the author uses a questionnaire method. Based on the \\ good criteria. The answers used in this study may be 39 people.
}

\section{INTRODUCTION}

The development of internet users in Indonesia is one of the factors in the rapid digitalization of various sectors. These sectors include communications, transportation, health, trade, education, finance, the digital industry, and so on. The trade sector is growing very rapidly, this can be seen with as many as seven unicorns in Southeast Asia, four of them in Indonesia [1].

The importance of information systems and technological developments that are constantly increasing and causing everyone and business people to continuously update their technology in order to keep up with technological developments currently used by most people.

Based on the published results of a survey conducted by Indonesian Internet Service Providers Association at the end of 2018, internet users in Indonesia reached 171.17 million from 264.16 million people or $64.8 \%$ of the total population[2].

Selection of a marketing strategy that focuses on efforts to create a relationship between the company and customers is a term Customer Relationship Management [3].

According to [4] Customer Relationship Management is used as a solution in overcoming problems in the business world in today's globalization era by developing 
technology and information systems. Science and technology serve as the foundation for opening a wider information network and conveying various types of information.

From the results of interviews with several businesses that were categorized as Small and Medium Enterprises, customers were not well managed. Customers are only maintained once a year. If there is good information about a product or a change in price they don't get it.Apart from this, many small and medium enterprises are still manual or have not used the system. From the surveys and interviews conducted, they really need a system. The system is expected to assist in managing customers. There are a lot of as Small and Medium Enterprise in the field of selling the Nine Staples and this is an opportunity for technological development.

The process of making and implementing ECommerce in as Small and Medium Enterprise is designed based on data processing of sales of basic necessities in the business.

System testing adapts the User Acceptance Test (UAT) model, this is a testing process by users that aims to produce documents that can be used as evidence that the system created can be accepted by users using the questionnaire method.

\section{LITERATURES REVIEW}

According to [5] Regulation of the Minister of Finance number 210/PMK/010/2018 concerning Taxation Treatment of Trading Transactions through Electronic Systems, it explains that an electronic platform is a container in the form of applications, websites, and / or other content services internet-based which is used for transactions and/or trade facilitation through an electronic system (e-commerce), while the electronic market (marketplace) is a means of electronic communication used for transactions aimed at conducting electronic trading business activities.

Online transaction processing systems have a very strategic role in commercial trade.Many companies use the internet, extranets, and other networks to bond with customers and suppliers using electronic means. They use online transaction processing (OLTP).The system can process transactions immediately, can help companies provide great service to customers and other trading partners.

The emergence of E-Commerce is largely built by several factors, including: (1) Evolution of the existence of computers and hardware and software, (2) Development of computer networks and the internet, (3) the digital era will change people's mindsets and lifestyles [6].

According to Law Number 20 of 2008, the definition of as Small and Medium Enterprise [7]:

1. Micro business is a productive business owned by an individual and/or an individual business entity that meets the criteria for a micro business.

2. Small business is a productive economic business that stands alone. This business is carried out by business entities or individuals. The business is not a subsidiary and not a branch of a company that is owned, controlled, or is a direct or indirect part of a medium or large business.

3. Medium enterprises are productive economic enterprises that stand alone. This business is carried out by individuals or business entities and is not a subsidiary or branch that is owned. This business is also not controlled or is a part, either directly or indirectly, of small or large businesses with total net assets or annual sales proceeds as stipulated in the Law.

According to [8], the criteria for Small and Medium Enterprise can be grouped into: 
1. Based on assets and turnover

Table 1. Criteria for Micro, Small and Medium Enterprise based on Assets and Turnover

\begin{tabular}{|l|l|l|}
\hline DESCRIPTION & \multicolumn{1}{|c|}{ ASESTS } & \multicolumn{1}{c|}{ TURNOVER } \\
\hline Micro business & $\begin{array}{l}\text { maximum of } \\
\text { Rp. 50 million }\end{array}$ & $\begin{array}{l}\text { Maximum Rp 300 } \\
\text { million }\end{array}$ \\
\hline Small business & $\begin{array}{l}>\mathrm{Rp} 50-500 \\
\text { million }\end{array}$ & $\begin{array}{l}>\mathrm{Rp} 300 \text { million } \\
-2,5 \text { billion }\end{array}$ \\
\hline $\begin{array}{l}\text { Medium } \\
\text { enterprises }\end{array}$ & $\begin{array}{l}>\mathrm{Rp} \mathrm{500} \\
\text { million - < } 1 \\
\text { billin }\end{array}$ & $\begin{array}{l}>\mathrm{Rp} 2,5 \text { billion - } \\
50 \text { billion }\end{array}$ \\
\hline
\end{tabular}

Source: Law Number 20 of 2008

2. Based on the number of workers

Table 2. Criteria for Micro, Small and Medium Enterprise based on Labor

\begin{tabular}{|l|l|}
\hline \multicolumn{1}{|c|}{ Group } & \multicolumn{1}{c|}{ Total Manpower } \\
\hline Micro business & Less than 4 people \\
\hline Small business & 5 to 19 people \\
\hline $\begin{array}{l}\text { Medium } \\
\text { enterprisess }\end{array}$ & 20 to 99 people \\
\hline
\end{tabular}

Source: Central Bureau of Statistics

According to [9], testing a software engineering product can be tested in one of the following test categories:

\section{a. Black-Box Testing}

This test focuses on the specifications of the software function. Tests can define a set of input conditions, and perform tests on the function specifications of a program. In addition, Black-box testing is carried out to find errors for each function of the program. Black-box testing is also designed to validate functional requirements without needing to know the internal workings of a program.

\section{b. User Acceptance Testing}

User Acceptance Testing is software testing that is used to find out whether there are defects or defects in the application or software being developed.

\section{FRAMEWORK}

The research conceptual framework :

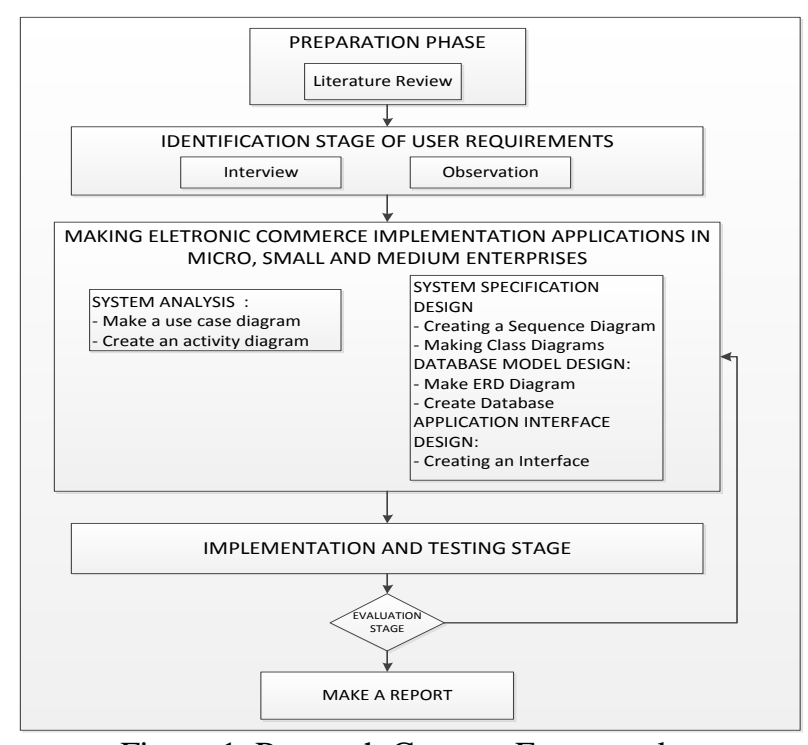

Figure 1. Research Concept Framework

The above conceptual framework can be explained as follows:

1. The researcher conducted a technology study in terms of various aspects of the current problems, and reviewed the institutional and information technology aspects.

2. System development method Rapid Application Development (RAD) is used to analyze and design software with the Unified Model Language. Coding using the PHP programming language and MySQL database, and testing the system using Black-Box Testing.

3. The application display is built so that users can input data to be stored into the MySQL database and one time the data can be displayed in the form of information with a more user friendly visual appearance and good user experience.This application can be accessed by system users with user level restrictions.

4. Tests carried out then conclude whether the system has met the requirements to pass the test based on the User Acceptance Testing method software.

\section{METHODS}

Based on the research objectives included in the type of development research.Development research is a method 
used to produce a product and test its effectiveness. Research and development methods have been frequently used in the field of information technology [10].

Methods of data collection by means of: interviews, observation, literature study, and documents.

User Acceptance Testing is software testing that is used to find out whether there are defects or defects in the application or software being developed.

User Acceptance Test is a testing process carried out by the user with the output of a test result document that can be used as evidence that the software created has been accepted by the user. In addition, the software that is made also meets the needs requested by customers or users.

According to [9], testing in software engineering is a series of stages that are implemented sequentially.

This test is to determine the quality of the software that is in the hypothesis. The criteria for selecting the characteristics of respondents as research samples for testing this software are based on the level of users in accessing the system.

Testing data processing using tools in the form of descriptive statistical analysis. The data collected consists of a description of the facts that are processed into data. From this data then analyzed in order to obtain a conclusion.

Descriptive statistics are a type of statistics used to analyze data by describing or describing the data that has been collected as is without making generalized conclusions or generalizations[10].

The development strategy or object-oriented system development is to organize and integrate a software system as a collection of objects containing data and operations that are enforced in a way that the system is built through a systematic object approach.

Sequence diagram can describe objects in a use case and a massage that runs in a use case. Sequence diagrams also describe objects and their relationships including the logical chronology of changes after receiving a message.
The system development method uses Rapid Application Development (RAD). This method is an option from the System Development Life Cycle (SDLC). Information systems development method with a relatively short time. The main objective of the RAD method is to provide a system that can meet user expectations. In fact, it often occurs when the development of a system does not involve the system users directly.

According to [11], Rapid Application Development is an incremental model of the software development process, especially because the time required is relatively short. The team must be able to understand the software requirements and must be limited in scope so that the team can complete the software creation in a short time.

The RAD model is implemented by dividing the development team into teams. All teams work on several components, the work of each team can be done in parallel.

1. Business Modeling

Modeling is done by creating a workflow that has been running, then modeling it using activity diagrams and use case diagrams. The needs include system users, both business owners and customers, so that users' information needs can be known. Besides that, it can also make it easier to create programs.

2. Data Modeling

Modeling the data needed by the system, namely: user data, goods, customers, suppliers, purchases, sales, inventory, and reporting data.

3. Process Modeling

Implement defined business functions related to defining data. Processing images are created to add, modify, delete or retrieve data objects. Modeling using sequence diagram tools.

4. Making Applications

Implementing process and data modeling into a program. In this process, it is created using the PHP programming language.

5. Testing and replacement 
Testing the components that are made, if they have been tested, the component development team can move on to developing the next component.

\section{RESULT}

System design can be described through :

a. Use Case: in this study divided into use cases: goods, suppliers, customers, purchases, sales, and use cases reports. In this article the author provides an example of 1 use case report.

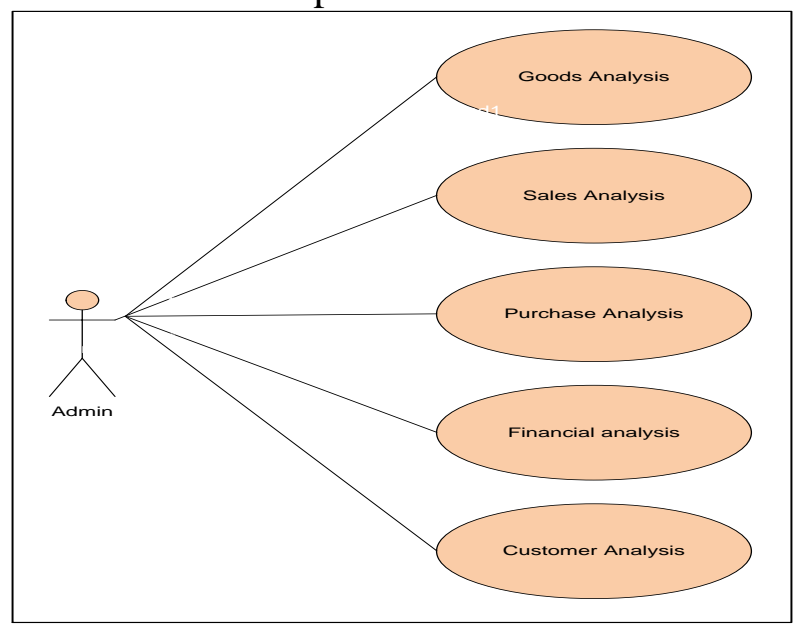

Figure 2 : Use Case Report

b. Activity Diagram: divided into customer registration activity diagrams, login processes, purchases, sales, and reports. The following is the activity login:

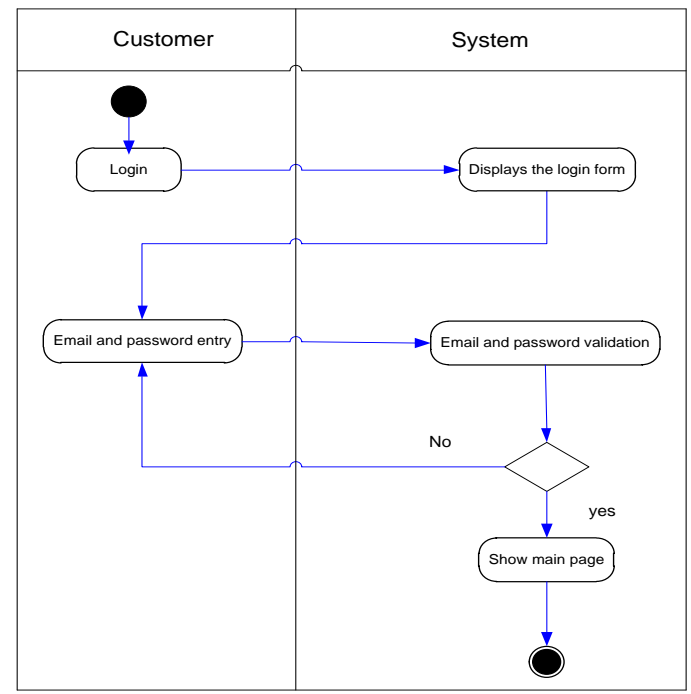

Figure 3 :Login Activity Diagram c. Sequence diagrams in this study consist of item data entry, customer data entry, supplier data entry, purchase data entry, sales data entry, and report sequence diagrams. The following is a sales sequence diagram:

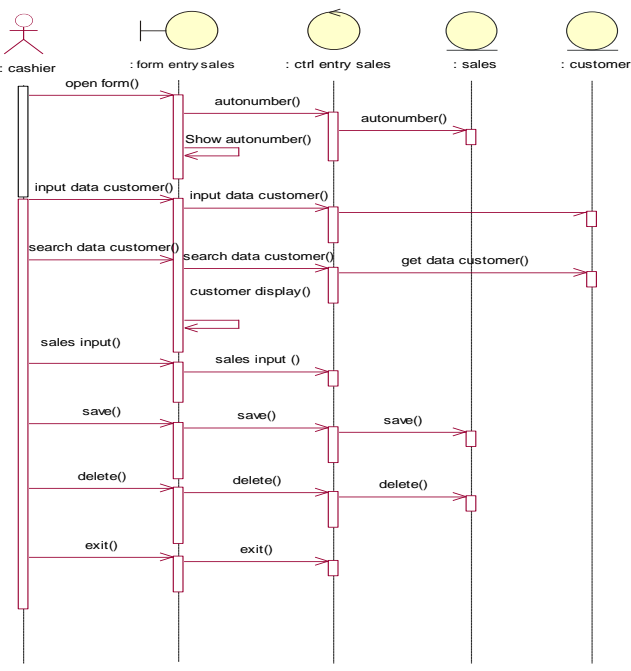

Figure 4: Sales Sequence Diagram

\section{DISCUSSION}

\section{System Testing and Implementation}

The Black Box testing method is a system testing method used to find errors and show the functionality of the application when it is run or operational. This testing includes whether the input is received correctly and the resulting output is as expected. In Black Box testing includes security and system performance.Tests carried out on six main parts include: testing on the login, testing on the product menu, testing on the customer menu, testing on the supplier menu, testing on the sales menu, and testing on the purchase menu. Based on these tests all get valid results.

\section{System Testing Using User Acceptance Test}

Respondents in this study filled out a questionnaire which contained the test and implementation of e-commerce in Small and Medium Enterprise. Respondents 'responses to the level of acceptance of this information system are taken based on respondents' answers. The answer is then measured using a formula : 
Actual score

$\%$ actual score $=$ x $100 \%$

Ideal score

From the formula above, the actual score is the sum of the answers to the questionnaire that has been submitted, while the ideal score is the sum of the maximum or highest values for all respondents. As an actualization explanation the actual score weights are:

Table3. Test Score Criteria

\begin{tabular}{|c|l|}
\hline$\%$ total score & \multicolumn{1}{|c|}{ Criteria } \\
\hline $20,00 \%-36,00 \%$ & Bad \\
\hline $36,01 \%-52,00 \%$ & Not good \\
\hline $52,01 \%-68,00 \%$ & Enough \\
\hline $68,01 \%-84,00 \%$ & Good \\
\hline $84,01 \%-100 \%$ & Very good \\
\hline
\end{tabular}

Testing was carried out using 7 questions given to 39 respondents. This is used to determine the response from customers to the system to be implemented. The answers to these questions are weighted to be:

Table 4. UAT answer choices

\begin{tabular}{|l|l|}
\hline A & Strongly disagree \\
\hline B & Disagree \\
\hline C & Neutral \\
\hline D & Agree \\
\hline E & Strongly disagree \\
\hline
\end{tabular}

Table 5. Weighted Answer Value

\begin{tabular}{|l|c|}
\hline \multicolumn{1}{|c|}{ Answer } & Value \\
\hline Strongly disagree & 1 \\
\hline Disagree & 2 \\
\hline Netral & 3 \\
\hline Agree & 4 \\
\hline Strongly disagree & 5 \\
\hline
\end{tabular}

Table 6. Questionnaire Question Data

\begin{tabular}{|c|c|c|c|c|c|c|c|c|c|c|}
\hline \multirow{2}{*}{ No. } & \multicolumn{7}{|c|}{ Answer } & \multicolumn{6}{|c|}{ Percent } \\
\cline { 2 - 11 } & A & B & C & D & E & A & B & C & D & E \\
\hline 1 & 7 & 24 & 4 & 3 & 1 & 17,9 & 61,5 & 10,3 & 7,7 & 2,6 \\
\hline 2 & 18 & 16 & 3 & 2 & 0 & 46,2 & 41,0 & 7,7 & 5,1 & 0,0 \\
\hline 3 & 7 & 26 & 3 & 1 & 2 & 17,9 & 66,7 & 7,7 & 2,6 & 5,1 \\
\hline 4 & 8 & 23 & 6 & 1 & 1 & 20,5 & 59,0 & 15,4 & 2,6 & 2,6 \\
\hline 5 & 21 & 11 & 4 & 2 & 1 & 53,8 & 28,2 & 10,3 & 5,1 & 2,6 \\
\hline 6 & 10 & 25 & 3 & 1 & 0 & 25,6 & 64,1 & 7,7 & 2,6 & 0,0 \\
\hline 7 & 12 & 17 & 5 & 3 & 2 & 30,8 & 43,6 & 12,8 & 7,7 & 5,1 \\
\hline
\end{tabular}

\begin{tabular}{|l|l|l|l|l|l|l|l|l|l|l|}
\hline 8 & 9 & 25 & 2 & 2 & 1 & 23,1 & 64,1 & 5,1 & 5,1 & 2,6 \\
\hline & 92 & 167 & 30 & 15 & 8 & 29,5 & 53,5 & 9,6 & 4,8 & 2,6 \\
\hline
\end{tabular}

Table 7. Weight of the Value and Answer

\begin{tabular}{|c|c|c|c|c|c|c|}
\hline \multirow{2}{*}{ Question } & \multicolumn{5}{|c|}{ Value } & \multirow{2}{*}{ Total } \\
\cline { 2 - 6 } & $\mathbf{A x 5}$ & $\mathbf{B x 4}$ & $\mathbf{C x 3}$ & $\mathbf{D x 2}$ & $\mathbf{E x 1}$ & \\
\hline Number 1 & 35 & 96 & 12 & 6 & 1 & 150 \\
\hline Number 2 & 90 & 64 & 9 & 4 & 0 & 167 \\
\hline Number 3 & 35 & 104 & 9 & 2 & 2 & 152 \\
\hline Number 4 & 40 & 92 & 18 & 2 & 1 & 153 \\
\hline Number 5 & 105 & 44 & 12 & 4 & 1 & 166 \\
\hline Number 6 & 50 & 100 & 9 & 2 & 0 & 161 \\
\hline Number 7 & 60 & 68 & 15 & 6 & 2 & 151 \\
\hline Number 8 & 45 & 100 & 6 & 4 & 1 & 156 \\
\hline Total & 460 & 668 & 90 & 30 & 8 & 1256 \\
\hline
\end{tabular}

The average value of the test using the UAT model is:

Table 8. Average Value of Test Results

\begin{tabular}{|l|c|c|c|}
\hline \multirow{2}{*}{ Descrition } & \multicolumn{3}{|c|}{ Research Result } \\
\cline { 2 - 4 } & $\begin{array}{c}\text { Actual } \\
\text { Score }\end{array}$ & $\begin{array}{c}\text { Yield } \\
\text { Value }\end{array}$ & Percent \\
\hline Question Number 1 & 195 & 150 & 76,9 \\
\hline Question Number 2 & 195 & 167 & 85,6 \\
\hline Question Number 3 & 195 & 152 & 77,9 \\
\hline Question Number 4 & 195 & 153 & 78,5 \\
\hline Question Number 5 & 195 & 166 & 85,1 \\
\hline Question Number 6 & 195 & 161 & 82,6 \\
\hline Question Number 7 & 195 & 151 & 77,4 \\
\hline Question Number 8 & 195 & 156 & 80,0 \\
\hline Total & 1560 & 1256 & 80,5 \\
\hline
\end{tabular}

Based on the data above, it is concluded that the system created can be well received by users and customers with a score of $80.5 \%$ (good)

\section{CONCLUSION}

In accordance with the problems, research reviews, literature studies, and research process models related to the implementation of e-commerce in Small and Medium 
Enterprise that have been carried out can be concluded as follows :

1. The use of information technology and market expansion using the e-commerce model that has been implemented can support the development of Small and Medium Enterprise.

2. Based on the results of software testing, the implementation of e-commerce in Small and Medium Enterpriseusing the User Acceptance Test (UAT) model carried out at Madika Stores achieves the expectation of "good" (80.5\%)

\section{ACKNOWLEDGEMENT}

The authors would like to express our gratitude for the support provided by Faculty of Science and technology. The financial assistance fromResearch, Publication and Community Service Department Buddhi Dharma University is also greatly acknowledged.

\section{REFERENCES}

[1] (Badan Ekonomi Kreatif BEKRAF, "Mapping \& Database Startup Indonesia 2018," 2018.

[2] (Asosiasi Penyelenggara Jasa Internet Indonesia) APJII, "Survei Nasional Penetrasi Pengguna Internet 2018," https://apjii.or.id/survei/2018, vol. Ver: S201, 2018, [Online]. Available: https://apjii.or.id/survei2018.

[3] P. Kotler, Manajemen Pemasaran, Ketiga. 2019.

[4] Tugiman, B. Amat, and D. Benny, "Customer Relationship Management System in Medika Lestari Hospitals," vol. 2, 2020, [Online]. Available: https://jurnal.buddhidharma.ac.id/index.php/te/article/view/324.

[5] PMK, "Peraturan Menteri Keuangan Nomor 210/PMK/010/2018," 2018.

[6] P. Agus Eka Pratama, E-Commerce, E-Business dan Mobile Commerce. Bandung: Informatika, 2015.

[7] Undang-undang, "Undang-undang Republik Indonesia nomor 20 tahun 2008 tentang Usaha Mikro, Kecil, dan Menengah," 2008.

[8] N. Tanjung, Koperasi dan UMKM Sebagai Fondasi Perekonomian Indonesia. Jakarta: Erlangga, 2016.

[9] Pressman, Rekayasa Perangkat Lunak, Edisi 7. YogyaKarta: Andi, 2012.

[10] Sudaryono, Metodologi Riset di Bidang TI. Yogyakarta: Andi Offset, 2014.

[11] Rosa A.S. Shalahudin M., Rekayasa Perangkat Lunak Terstruktur dan berorientasi Objek, Infromatik. bandung, 2013.

\section{BIOGRAPHY}

Tugiman, Graduated in the Information Technology Study Program (S1) in 2014, continued his Masters in Information Systems in 2014 and graduated in 2016. He is currently a Lecturer Information Systems Study Program in Buddhi Dharma University.

Dellih Wijaya, Graduated from the Information System Study Program (S1) in 2003, continued his Masters in Management in 2005 and graduated in 2009. She currently serves as a Lecturer in Information Systems Study Program, Buddhi Dharma University. 
Yakub, Lecturer at Buddhi Dharma University, Tangerang. Graduates (S1) Information System STMIK Widuri Jakarta, 2002, (S2) Master Computer Eresha School of Information Technology, 2005, (S2) Master of Management of Budi Luhur University, 2008, (S3) Doctoral University of Islam Nusantara Bandung, 2014. 